\title{
Regeneração in vitro de brotações de Pereira (Pyrus communis L.) cultivar Carrick ${ }^{1}$
}

\author{
In vitro regeneration of shoots of pear (Pyrus communis L.) cv. \\ Carrick
}

\author{
Alan Cristiano Erig ${ }^{2}$ Márcia Wulff Schuch ${ }^{3}$
}

\section{RESUMO}

O objetivo deste trabalho foi obter um protocolo de regeneração de brotações in vitro a partir de explantes de pereira (Pyrus communis L.) cultivar Carrick, visando a programas de transformação genética. Para tanto, utilizaram-se três tipos de explantes (ápice caulinar, folha e entrenó) que permaneceram durante 0, 10, 20, 30 ou 40 dias em meio de indução e, posteriormente, foram transferidos para meio de proliferação com 8,9 ou 13,3 $4 M$ de thidiazuron (TDZ). Aos 85 dias após o início do experimento, observou-se que o explante ápice caulinar apresentou maior capacidade de regeneração de brotações quando comparado ao explante entrenó, enquanto o explante folha não mostrou capacidade de regenerar brotações. Verificouse também que, inoculando o explante diretamente em meio de proliferação sem auxina, houve uma maior percentagem de regeneração e que, aumentando o tempo de permanência dos explantes em meio de indução, diminuiu a percentagem de regeneração de brotações. A concentração de thidiazuron (TDZ) no meio de proliferação não afetou a capacidade de regeneração de brotações.

Palavras-chave: cultura de tecidos; organogênese; thidiazuron.

\section{ABSTRACT}

The objective of this work was to obtain a shooting regeneration protocol from explants of pear tree (Pyrus communis L.) Carrick cultivar, aiming at genetic transformation programs. Three types of explants (caulinary tip, leaf and entrenode) were used. They were left for 0, 10, 20, 30 or 40 days in induction medium, and afterwards they were transferred to proliferation medium with 8.9 or $13.3 \mu M$ of TDZ. At 85 days after the beginning of the experiment, it was noted that the caulinary tip explant showed higher capacity of shooting regeneration when compared to entrenode explants, while the leaf explant was not able to regenerate. It was also observed that inoculating the explant directly in proliferation medium without auxin resulted in a higher percentage of regeneration, and increasing the period of time that the explants remained in induction medium lowered the percentage of regeneration of shoots. The TDZ concentration in the proliferation medium did not affect the capacity of shooting regeneration.

Key words: tissue culture; organogenesis; thidiazuron.

\section{INTRODUÇÃO}

Apesar da grande diversidade genética nas espécies frutíferas, a produção de frutas, em geral, é dependente de um limitado número de cultivares. Em particular, para a pêra (Pyrus communis L.), grande parte da produção mundial é baseada em menos de dez variedades (MOURGUES et al., 1996).

Em termos de classificação, as cultivares de pêra mais consumidas no mundo podem ser divididas em dois tipos: européias (Pyrus communis) e asiáticas

${ }^{1}$ Parte da dissertação de mestrado do primeiro autor, apresentada ao Programa de Pós-graduação em Agronomia (PPGA), Faculdade de Agronomia Eliseu Maciel, Universidade Federal de Pelotas (FAEM/UFPel). Apoio FAPERGS.

${ }^{2}$ Engenheiro Agrônomo, Aluno do PPGA, área de concentração em Fruticultura de Clima Temperado, FAEM/UFPel, CP 354, 96.010-900, Pelotas, RS. E-mail: acerig@ufpel.the.br. Autor para correspondência.

${ }^{3}$ Engenheira Agrônoma, Doutora, Professora do Departamento de Fitotecnia, FAEM/UFPel, CP 354, 96.010-900, Pelotas, RS. E-mail: marciaws@ufpel.the.br 
(Pyrus pyrifolia var. Culta, Pyrus bretschneideri e Pyrus ussuriensis) (FAORO \& YASUNOBU, 2001). A cultivar Carrick, pertencente à espécie Pyrus communis L., é originária dos Estados Unidos, proveniente do cruzamento entre as cultivares Seckel x Garber (BROOKS \& OLMO, 1972).

Em geral, as espécies frutíferas são perenes, de longo ciclo vegetativo, de porte relativamente grande e com alto nível de heterozigosidade, o que dificulta e aumenta o tempo necessário para um programa de melhoramento genético através do método convencional de hibridização (CABONI et al., 2000). Neste respeito, a introdução de características agronômicas importantes pela transformação genética, pode oferecer um método alternativo rápido para o melhoramento da pereira, sem causar recombinação no genoma das principais cultivares comerciais, segundo MOURGUES et al. (1996).

A maior dificuldade para a obtenção de plantas transgênicas é o estabelecimento prévio de um sistema de regeneração eficiente (BRASILEIRO \& DUSI, 1999). Na regeneração de plantas lenhosas, geralmente os explantes mais utilizados são folhas e entrenós, o que mostram os trabalhos de SEMERIA et al. (1996) e PELLEGRINESCHI \& MARIANI (1996). Estes precisam ser seccionados, de acordo com YAO et al. (1995) para que haja uma proliferação celular com formação de tecidos de cicatrização e zonas de intensa atividade meristemática.

Uma outra possibilidade é a utilização direta de tecidos meristemáticos, especialmente ápices caulinares e radiculares (KUNIEDA \& KERBAUY, 1986), nos quais ocorre grande homogeneidade e as células estão sempre num processo ativo de divisão, o que facilita a indução dos processos organogenéticos (HANDRO \& FLOH, 1990).

Atenção tem sido dada ao tipo, à concentração e ao período de tempo em que os reguladores de crescimento são mantidos na cultura (AMMIRATO, 1989). Segundo LEBLAY et al. (1991), o processo de regeneração pode ser subdividido em duas fases, indução e expressão, tornando-se importante conhecer a duração destas duas fases e as suas exigências em reguladores de crescimento.

O potencial para organogênese é extenso dentro do gênero Pyrus, sendo necessária a otimização de um protocolo de regeneração para diferentes cultivares, pois existe uma variação de resposta dentro deste gênero (CHEVREAU et al., 1989).

O objetivo deste trabalho foi obter um protocolo de regeneração de brotações a partir de diferentes explantes de pereira (Pyrus communis L.) cultivar Carrick, visando a programas de transformação genética.

\section{MATERIAL E MÉTODOS}

O trabalho foi realizado no Laboratório de Cultura de Células e Tecidos de Plantas, Departamento de Botânica do Instituto de Biologia, da Universidade Federal de Pelotas, RS.

Utilizaram-se três tipos de explantes (ápice caulinar, folha e entrenó), que permaneceram durante $0,10,20,30$ ou 40 dias em meio de indução e posteriormente foram transferidos para meio de proliferação com 8,9 ou 13,3 $\mu \mathrm{M}$ de TDZ, totalizando 30 tratamentos.

Os explantes foram retirados de plantas cultivadas in vitro, em fase de multiplicação, 35 dias após a repicagem. Os ápices caulinares, constituídos pelo meristema e primórdios foliares, foram isolados de gemas apicais das brotações. O explante folha constituiu de folhas inteiras excisadas em dois locais perpendicularmente a nervura central e, colocados com a face adaxial em contato com o meio. Os entrenós constituíram de segmentos do caule, medindo 0,2 a $0,3 \mathrm{~cm}$ de comprimento.

O meio de cultura de indução foi composto pela formulação salina MS (MURASHIGE \& SKOOG, 1962), suplementada com $4,4 \mu \mathrm{M}$ de TDZ, $1,1 \mu \mathrm{M}$ de ANA, 100 $\mathrm{mg} \mathrm{L}^{-1}$ de mio-inositol, 30g. $\mathrm{L}^{-1}$ de sacarose e $6 \mathrm{~g} \mathrm{~L}^{-1}$ de ágar.

Transcorrido o tempo de permanência no meio de indução, os explantes foram transferidos para meio de proliferação, constituído de meio de cultura basal MS, suplementado com 8,9 ou $13,3 \mu \mathrm{M}$ de TDZ, conforme o tratamento. Os meios de cultura de indução e de proliferação, tiveram o $\mathrm{pH}$ ajustado para 5,8 antes da inclusão do ágar e, posteriormente, autoclavados a $121^{\circ} \mathrm{C}$ e $1,5 \mathrm{~atm}$ por 15 minutos. Para ambos os meios, foram utilizados frascos de $200 \mathrm{~mL}$ com $30 \mathrm{~mL}$ de meio de cultura.

Após a inoculação, os explantes foram mantidos em sala de crescimento no escuro durante duas semanas e, em seguida, foram transferidos para sala de crescimento com 16 horas de foroperíodo, temperatura de $25 \pm 2^{\circ} \mathrm{C}$ e radiação de $25 \mu$ moles $\mathrm{m}^{-2} \mathrm{~s}^{-1}$.

$\mathrm{O}$ delineamento experimental utilizado foi o inteiramente casualizado, com cinco repetições por tratamento. Cada repetição constituiu de um frasco com cinco explantes.

Dados de percentagem de regeneração, número médio de brotações por explante e comprimento da brotação mais desenvolvida, foram coletados em 85 dias de cultivo. Os dados foram submetidos à análise de variância e as médias dos tratamentos comparadas estatisticamente pelo teste de Duncan ou analisadas por regressão polinomial, através do uso do pacote 
estatístico SANEST (ZONTA \& MACHADO, 1987).

Dados originais expressos em percentagem foram transformados em arc sen $(\mathrm{x}+0,5)^{0,5}$, e os dados do número médio de brotações por explante foram transformados em $(\mathrm{x}+0,5)^{0,5}$.

\section{RESULTADOS E DISCUSSÃO}

Para as três variáveis avaliadas, a análise de variância indicou efeito significativo da interação tipo de explante e tempo de permanência em meio de indução.

Observou-se que ápices caulinares inoculados diretamente em meio de proliferação, sem passar pelo meio de indução, resultaram em maior percentagem de regeneração de brotos $(90,6 \%$ ) (Figura 1). $\mathrm{O}$ aumento do tempo de permanência em meio de indução promoveu uma redução na percentagem de regeneração, obtendo-se o menor valor com 40 dias $(26,1 \%)$.

Resultado semelhante foi encontrado por CABONI et al. (2000), que estudaram o efeito da fase de indução na habilidade de regeneração de ápices caulinares de macieira cv. Jork-9. Estes autores observaram que, prolongando o período de permanência dos explantes em meio de indução para 30 dias, a regeneração de brotos não foi tão eficiente (68\%) como aquela obtida ao se manter os explantes por 20 dias em meio de indução $(100 \%)$.

O uso de entrenó, como explantes e inoculados diretamente em meio de expressão, também foi observado uma maior percentagem de regeneração de brotos (36,4\%). Quando o explante entrenó permaneceu durante 22,3 ou mais dias em meio de indução, não houve regeneração de brotos. Já CUENCA et al. (2000) obtiveram regeneração de brotações a partir de entrenós de clones de Fagus sylvatica e de Fagus orientalis, mantendo-os, durante 30 dias em meio de indução e transferindo-os, posteriormente, para meio de proliferação.

O explante folha apresentou zero \% de regeneração, independentemente do tempo de permanência emmeio de indução. CHEVREAU \& LEBLAY (1993) demonstraram que o estádio fisiológico de desenvolvimento da folha de pereira é um fator determinante para a regeneração de brotos. Provavelmente isso explique o resultado obtido no presente trabalho, no qual não houve regeneração a partir de folhas coletadas de brotações com 35 dias de cultivo.

O explante ápice caulinar apresentou maior percentagem de regeneração, diferindo significativamente dos explantes entrenó e folha, independentemente do tempo de permanência em meio de indução (Tabela 1). Segundo CARPUTO et al. (1995), o explante ideal deve ser estabelecido para cada genótipo de interesse, pois há genótipos em que as folhas apresentam melhores resultados e outros em que os entrenós são mais regenerativos.

De maneira geral, observou-se no presente trabalho que a manutenção dos explantes, durante zero dias em meio de indução, não promoveu a formação de calo. No entanto, naqueles mantidos durante 10, 20,30 e 40 dias em meio de indução, houve uma pequena formação de calo no local de excisão. E a formação de calo aumentou com o número de dias que as culturas foram transferidas para o meio de proliferação sem auxina. Contudo, foi observado que as brotações originaram-se diretamente a partir de tecidos do explante (Dados não mostrados). Em certos casos, a cultura in vitro não promove a formação de calos, mas apenas uma proliferação celular restrita às regiões seccionadas do explante,
Figura 1 - Percentagem de regeneração de brotos de pereira cv. Carrick, em função do tipo de explante e do tempo de permanência no meio de indução (dias), aos 85 dias de cultivo. Pelotas, RS, 2002. 
Tabela 1 - Percentagem de regeneração de brotos de pereira cv. Carrick, em função do tipo de explante e do tempo de permanência no meio de indução (dias), aos 85 dias de cultivo. Pelotas, RS, 2002.

\begin{tabular}{|c|c|c|c|c|c|}
\hline \multirow{2}{*}{$\begin{array}{l}\text { Tipo de } \\
\text { explante }\end{array}$} & \multicolumn{5}{|c|}{ Dias no meio de indução } \\
\hline & 0 & 10 & 20 & 30 & 40 \\
\hline Ápice caulinar & $87,28 a^{*}$ & $85,91 \mathrm{a}$ & $45,98 \mathrm{a}$ & $45,78 \mathrm{a}$ & $26,77 \mathrm{a}$ \\
\hline Entrenó & $39,42 b$ & $7,54 \mathrm{~b}$ & $5,28 b$ & $0,0 \mathrm{~b}$ & $0,0 \mathrm{~b}$ \\
\hline Folha & $0,0 \mathrm{c}$ & $0,0 \mathrm{c}$ & $0,0 \mathrm{c}$ & $0,0 \mathrm{~b}$ & $0,0 \mathrm{~b}$ \\
\hline
\end{tabular}

* Médias não seguidas de mesma letra, nas colunas, diferem pelo teste de Duncan em nível de 5\% de probabilidade de erro.

com formação de tecidos de cicatrização e zonas de intensa atividade meristemática (HANDRO \& FLOH, 1990).

Esta formação de calo, provavelmente, pode ter sido a causa da menor percentagem de regeneração obtida naqueles explantes que permaneceram mais tempo em meio de indução.

$\mathrm{Na}$ figura 2, observa-se que, com o explante ápice caulinar, obteve-se uma média de 1,4 brotações por explante, independentemente do tempo de permanência em meio de indução. Já para o explante entrenó, observou-se um comportamento linear decrescente, obtendo-se o maior número médio de brotações $(1,4)$ quando este foi inoculado diretamente em meio de proliferação. Já no explante folha, como não houve regeneração, não foram observadas brotações.

Trabalhando com a macieira cv. Jork-9, CABONI et al. (2000) obtiveram o maior número de brotações $(19,1)$ quando o ápice caulinar permaneceu durante 20 dias em meio de indução. FARIA (1996) obteve o maior número de brotações, utilizando entrenós do porta-enxerto Marubakaido (5,6 brotações), enquanto as folhas excisadas e as inteiras praticamente não regeneraram.

Observa-se, na figura 3, que, com o explante ápice caulinar, obteve-se um comprimento de $0,3 \mathrm{~cm}$ para a brotação mais desenvolvida, independentemente do tempo de permanência em meio de indução. Já para o explante entrenó, observou-se uma tendência linear decrescente, obtendo-se o máximo comprimento da brotação mais desenvolvida $(0,4 \mathrm{~cm})$, quando este explante foi inoculado diretamente em meio de proliferação, isto é, permanecendo zero dias em meio de indução.

De maneira geral, nota-se, que o comprimento das brotações mais desenvolvidas, no presente trabalho, é pequeno. Nos 85 dias de cultivo observouse que as brotações desenvolveram-se em forma de roseta, não apresentando elongação dos entrenós. Possivelmente, este fator é resultante do longo período de exposição a doses relativamente elevadas de TDZ. Segundo LU (1993), deve-se evitar exposições prolongadas ao TDZ, uma vez que este fitorregulador pode causar morfologia anormal às brotações. Portanto, é necessário transferir os brotos para um meio de elongação contendo níveis mais baixos de TDZ (HUETTEMAN \& PREECE, 1993). FARIA (1996) observou que o maior comprimento de brotações de Marubakaido, regeneradas a partir de entrenós, foi obtido com $5 \mu \mathrm{M}$ de BAP, havendo uma diminuição à medida que a concentração do BAP e TDZ aumentava. 


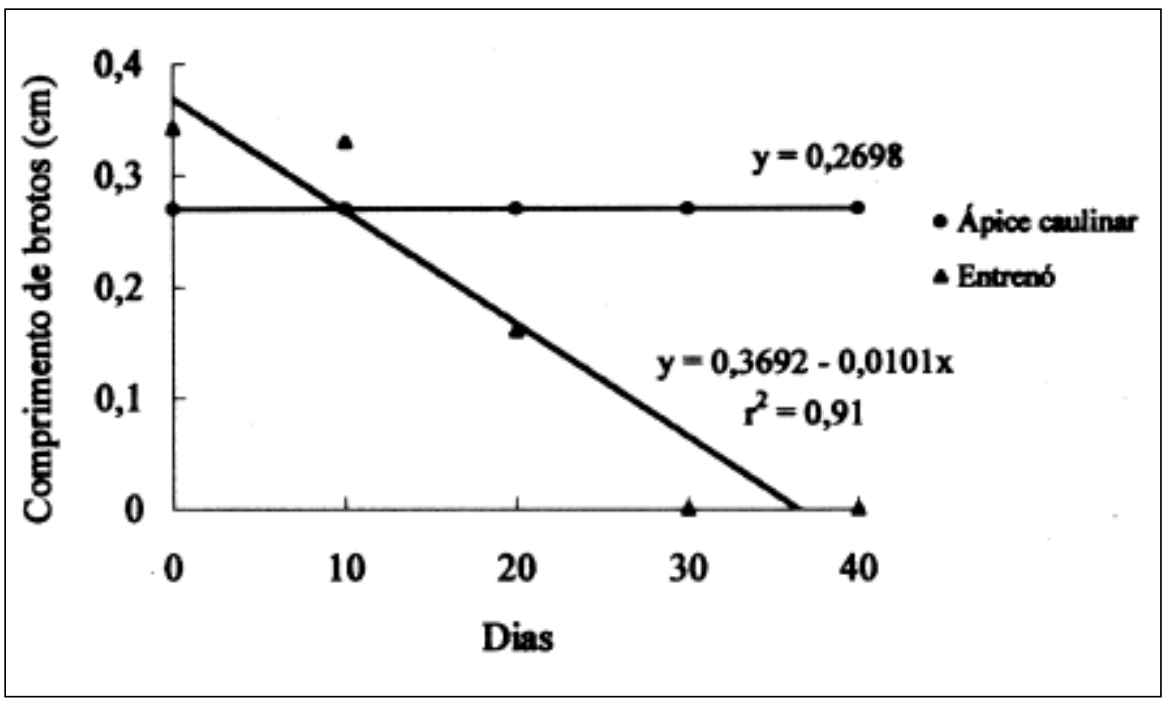

Figura 3 - Comprimento médio da brotação mais desenvolvida em explantes de pereira cv. Carrick, em função do tipo de explante e do tempo de permanência no meio de indução (dias), aos 85 dias de cultivo. Pelotas, RS, 2002. pretreatment and explant choice on regeneration from in vitro pear leaves. Acta Horticulturae, The Hague, n.336, p.263-268, 1993.

CHEVREAU, E. et al. Adventitious shoot regeneration from leaf tissue of three pear (Pyrus spp.) cultivars in vitro. Plant Cell Reports, New York, v.7, p.688-691, 1989.

CUENCA, B.; BALLESTER, A.; VIEITEZ, A. M. In vitro adventitious bud regeneration from internodes segments of beech. Plant Cell, Tissue and Organ Culture, Hague, v.60, n.3, p.213-220, 2000.

FAORO, I. D.; YASUNOBU, Y. Cultivares e porta-enxertos de pereira japonesa. JICA Boletim Informativo, Caçador, n.3, p.7, 2001 .

\section{CONCLUSÕES}

Nas condições em que foi desenvolvido o trabalho, os resultados permitem concluir que: o explante ápice caulinar apresentou maior capacidade de regeneração de brotações; a inoculação do explante diretamente em meio de proliferação sem auxina, favoreceu uma maior percentagem de regeneração de brotos; e a concentração de TDZ no meio de proliferação não afetou a capacidade de regeneração de brotações.

\section{REFERÊNCIAS BIBLIOGRÁFICAS}

AMMIRATO, P.V. Recent progress in somatic embryogenesis. Newsletter International Association of Plant Tissue Culture, Calgary, v.57, p.2-16, 1989.

BRASILEIRO, A.C.M.; DUSI, D.M.A. Transformação genética de plantas. In: TORRES, A.C.; CALDAS, L.S.; BUSO, J.A. Cultura de tecidos e transformação genética de plantas Brasília : SPI / Embrapa - CNPH, 1999. V.2, p.679-735.

BROOKS, R.M.; OLMO, H.P. Register of pear varieties. In: Register of new fruit \& nut varieties. 2.ed.

Berkeley : University of California, 1972. p.446-467.

CABONI, E.; LAURI, P.; D'ANGELI, S. In vitro plant regeneration from callus of shoot apices in apple shoot culture. Plant Cell Reports, New York, v.19, p.755-760, 2000.

CARPUTO, D. et al. Tissue culture response in various wild and cultived Solanum germplasm accessions for exploitation in potato breeding. Plant Cell, Tissue and Organ Culture, Hague, v.1, p.151-158, 1995.

CHEVREAU, E.; LEBLAY, C. The effect of mother plant
FARIA, J.T.C. Calogênese e organogênese in vitro em porta-enxerto de macieira cv. Marubakaido. 1996. $50 \mathrm{f}$. Dissertação (Mestrado em Agronomia - Fitomelhoramento) Faculdade de Agronomia Eliseu Maciel, UFPel.

HANDRO, W.; FLOH, E.I.S. Aspectos básicos do controle da morfogênese in vitro. In: TORRES, A.C.; CALDAS, L.S. (eds). Técnicas e aplicações da cultura de tecidos de plantas. Brasília : ABCTP / Embrapa - CNPH, 1990. p.203-212.

HUETTEMAN, C.A.; PREECE, J.E. Thidiazuron: a potent cytokinin for woody plant tissue culture. Plant Cell, Tissue and Organ Culture, Hague, v.33, n.2, p.105-119, 1993.

KUNIEDA, M.K.; KERBAUY, G.B. Formação de gemas em raízes adventícias de couve-flor cultivadas in vitro. Revista Brasileira de Botânica, São Paulo, n.9, p.231238, 1986.

LEBLAY, C.; CHEVREAU, E.; RABOIN, L.M. Adventitious shoot regeneration from in vitro leaves of several pear cultivars (Pyrus communis L.). Plant Cell, Tissue and Organ Culture, Hague, v.25, p.99-105, 1991.

LU, C.Y. The use of thidiazuron in tissue culture. In vitro Cellular and Developmental Biology Plant, New York, v.29, n.2, p.92-96, 1993.

MOURGUES, F. et al. Efficient Agrobacterium - mediated transformation and recovery of transgenic plants from pear (Pyrus communis L.). Plant Cell Reports, New York, v.16, p.245-249, 1996.

MURASHIGE, T.; SKOOG, F. A revised medium for rapid growth and biossay with tobacco tissue cultures. Physiologia Plantarum, Kobenhavn, v.15, p.473-497, 1962.

PELLEGRINESCHI, A.; MARIANI, O.D. Agrobacterium rhizogenes - mediated transformation of scented geranium. Plant Cell, Tissue and Organ Culture, Hague, v.47, p.79-86, 1996.

Ciência Rural, v. 33, n. 3, mai-jun, 2003. 
SEMERIA, L. et al. Genetic transformation of Eustoma grandiflorum by Agrobacterium tumefaciens. Plant Cell, Tissue and Organ Culture, Hague, v.47, p.67-72, 1996.

YAO, J. L. et al. Regeneration of transgenic plants from the commercial apple cultivar Royal Gala. Plant Cell Reports,
New York, v.14, p.407-412, 1995.

ZONTA, E.P.; MACHADO, A.A. SANEST - Sistema de análise estatística para microcomputadores. Pelotas : DMEC/IFM/UFPel, 1987. 138p.

Ciência Rural, v. 33, n. 3, mai-jun, 2003. 